$E-551$

PROGRESS REPORT ON STUDIES OF HYPERA BRUNNEIPENNIS (BOH.) I/ IN THE YUMA VALLEY OF ARIZONA

By William C. MoDuffie, Division of Cereal and Forage Insect Investigations

\title{
INTRODUCTION
}

On April 11, 1939, an insect believed to be the alfalfa weevil Hypera postica (Gyll.) was discovered feeding on fenugreek (Trigonella foenum-graecum L.) and alfalfa (Medicago sativa L.) near Yuma, Ariz., by L. P. Wehrle and Robert Flack of the University of Arizona Agricultural Experiment Station. Specimens submitted to the Bureau of Entomology and Plant Quarantine were determined by L. L. Buchanan as Hypera brunneipennis (Boh.), an insect occurring in Egypt, Ethiopia, and India but new to the United States. Other than a brief summary of its habits and development in Egypt by Willcocks, $\underline{2} /$ and the indication that it is a minor pest there on berseem clover (Trifolium alexandrinum L.), nothing was recorded of this insect in entomological literature.

A preliminary survey of the Yuma Valley by J. L. E. Lauderdale and other Arizona State workers immediately following the discovery revealed the infestation to be confined to the northeast portion of the tract. Further investigation during the spring by J. C. Hamlin and W. C. McDuffie, of the Bureau of Entomology and Plant Quarantine, and California State inspectors revealed an extension of the infestation about 1 mile north of Yuma near Winterhaven, Imperial County, Calif. Other areas in California and Arizona were examined, but no further infestations were found at that time.

1/ Order Coleoptera, family Curculionidae.

2/ Willcocks, F. C. A Survey of the More Important Insects and Mites of Egypt. Sultanic Agr. Soc., Tech. Sec., Bul. No. 1. 1922. (See pp. 43-44.) 
In adilition to fenugreek and alfalfa, Hypera brunneipennis was found to be feeding on bur-clover (Medicago hispida Gaertn.), hubam (annual form of Melilotus alba Desr.), and sourclover (Melilotus indica L.). The sourclover is of general occurrence on uncultivated areas in the Yuma Valley. Sufficient feeding occurred cl: this plant to be classed as eccncmic damage. Bur-clover in one small field was also heavily attacked. Nothing definite concerning the suitability of alfalfa as a host was determined, since the first and a portion of the second crop had been harvested prior to the discovery of the weevil. Consequertly, the econcmic importance of the weevil as a pest of alfalfa could not be evaluated until the advent of another larval brood.

A prelimirary investigation during the last days of April 1939 showed that larvae were scarce and mostly mature, cocccrs containing pupae were fairly numerous, and adults were extremely abunciant in the few heavily infested spots. It was thus apparent that a brood was almost ccmpleted and that little could be determired until arother appeared. The immediate consideration was whether or not this would occur immediately and endanger the valuable summer alfalfa seed crcp. Subsequent âscovery that adults were apparently aestivating, together with studies shcwing the sexual immaturity of bcth males and females, appeared to incicate a period of inactivity which might pcssibly exterd throligh the extreme summe heat into early fall. Nevertheless, it was deciced tc ccrtinue the studies under the supervision of $J$. C. Hamlin as a part of the Bureau's alfalfa Heevil investigations, and for this purpose a substation of the Salt Lake City, Utah, office of the Alfalfa Weevil Investigation was established at Yuma aring June 1939. This paper is an account of the rindings during the first year.

\section{EXTENT OF INFESTATION}

Sccuting in 1939 incicated that Hypera brunneipennis was confined to the Yuma Reclamatiois Project, mustly to the northeast portion of the Yuma Valley, Yuma County, Ariz., in an area approximately 8 miles long and 2 miles wide. A small extension of this area was found immediately north of Yuma on the Fort Yuma Indian Reservatior near Winterhaven, Imperial County, Calif. Further scouting outward from these limits and in other suspected areas of California and Arizona gave negative results. However, the lear-completion of the larval brood cast doubt on the validity of the survey.

In 1940, as soon as the irsect resumed activity in the fields, a thorough survey was concucted by the Bureau of Entcmology and Plant Quarantine in cocperation with the Arizora State Entomologist's office and the Califorria State Department of Agriculture. Preliminary scouting during January and February resulted in corsicierable extersion of the area known to be infested in the Yuma Valley ald in the California portion of the Yuma Reclamation Project. Two small infestations were also discovered in the Gila Valley, northeast and east of Yuma All these infestations, however, were within a radius of abuut 9 miles from the city. 
A small but important infestation was found on the University of Arizona Date Experiment Farm near Tempe, Maricopa County, Ariz. This infestation was limited to a few square rods, and eradication measures were applied by the State Entomologist, Mr. J. L. E. Lauderdale. The area within a 3 -mile radius was placed under State quarantine.

Intensive scouting throughout southern and central California and southern Arizona failed to reveal other infestations of $\underline{H}$. brunneipeninis.

\section{METHODS OF SPREAD}

The manner in which Hypera brunneipennis was introduced into the United States is unknown, but two possibilities have been advanced. These are, first, through importation of date palm stock from Egypt some 20 or 30 years ago, and second, through movement of produce or transients from other portions of the United States or Mexico not now known to be infested. The first possibility offers the most reasonable solution, since it is known that large numbers of adults aestivate among the stubs of the old leaf stems attached to the bases of date trees in the Yuma Valley. In view of this fact it seems probable that the infestation at Tempe, Ariz., can be attributed to adults carried there with date palm offshoots from the Yuma Valley in 1937 or 1938 . The principal evidence against $\underline{H}$. brunneipennis having been introduced through this medium is the fact that infestations have not been found in other date-growing areas, some of which are older plantings than those of the Yuma Valley, notably at Indio, Calif. There is, of course, a possibility that the insect has been introduced into other areas but that certain factors have prevented its establishment.

During the summer of 1939 a study was begun to determine the possibility of weevil spread from the Yuma Valley through shipments of various agricultural products. To date, only alfalfa seed and flax seed have been studied thoroughly. The work on alfalfa seed indicated little canger of weevil spread through shipment of this product. Factors supporting this conclusion were (1) the apparent absence of weevils from alfalfa fields during the seed harvest (July 15 to August 15), (2) the effectiveness of threshing machines in destroying and preventing entrance into the seed of artificially introduced weevils, (3) the effectiveness of recleaning in eliminating all foreign material from the thresher-run seed, and (4) the unlikelihood of contamination from mill premises. A similar study of flax, however, indicated a distinct possibility of weevil dissemination through shipment of flax seed, since (I) weevils occur in most fields on volunteer host plants, (2) a few adults remain in fields during the period of flax harvest (late in May to July 1), and (3) flax threshing machines do not destroy adults or prevent their entrance into the seed. Furthermore, examination of seed from a representative flax field revealed the natural occurrence of an occasional adult. Biological studies to date in Yuma Valley indicate that weevils which remain in fields as late as flax harvest are abnormal and do not reproduce or survive the summer. If this is true there apparently would be little danger of establishment resulting from their 
accidontal istribution into uninfested areas, although there is no certainty that they would not recover and reproduce where the climate is more temperate than in the Yuma Valley. In this regard, however, it appears likely that the current requirement that flax seed be shipped direct to the mills for immediate processing, or fumigated when it is to be sold for seed, would practically remove the possibility of weevils escaping.

The most likely means of weevil spread would be through shipment of baled alfalfa hay and date palm offshoots. However, fumigation of these is required. A iariety of other products shipped from Yuma Valley may possibly spread the weevil, kut none of these have been investigated as yet. Spread may also occur through the medium of vehicular traffic and through natural dissemination, but nothing is definitely known of the possibilities in either case.

\section{THE ADULT STAGE}

\section{Description}

The acult of Hypera brunneipennis ( $\mathrm{fig} .1, \mathrm{~A}$ and B) is a small snout beetlo approximately three-sixteenths of an inch in length. The newly emerged weevil is bronze in color but within a short while becomes brown. The adult loses its covering of hairs and becomes shiny black when old. In appearance the adult is very similar to the alfalfa weevil (ㅂ. postica). but because of a slight difference in the contour of the back it is possible to distinguish between the two species.

\section{Emergence of Adults}

The first new adults during the 1940 season were collected from sourclover on March 13. The finding of pupae 2 weeks before, however. suggests that a few adults may have emerged slightly earlier. After March 13 the abundance of new adults increased steadily to a peak of 4 per square foot in sourclover on April 22, in spite of the fact that small numbers began co migrate from the field to aestivation quarters about April 1. On April 29 acults were equally abundant, but the scarcity of cocoons and larvae showed clearly that production of adults was virtually completed. Therefore, it is indicated that the heaviest emergence of new adults occurred curing the 6week period from mid-March to late in April.

\section{Post-emergence Activity of Adults}

After emergence from cocoons, new adults fed heavily on the nearest arailable succulent leguminous host, principally on the leaves. Large numbers of adults partially or completely defoliated some plants and also fed to some extent on the epidermis of stems. The post-emergence feeding period lasted from 2 to 3 weeks. Feeding ceased rather abruptly, and most adults migrated from fields in search of places for aestivation, where they remained inctive throughout the summer and early fall months. 
A few adults fed by day, but the heaviest feeding occurred at night, especially during the late spring when daily maximum temperatures approached or exceeded $100^{\circ} \mathrm{F}$. During such temperatures adults preferred to remain under cover on or near the ground in comparative inactivity. When the cover in feeding areas was inadequate, adults concentrated in nearby grassy areas or in soil cracks during the day and returned at night to resume feeding.

An occasional adult aestivated in feeding areas where adequate ground cover existed, but virtually all left these areas to congregate in situations affording more suitable protection. A few individuals remained active in fields and could be swept from them at night until the hay harvest late in June. Thereafter, neither sweeping nor examination of debris from fields revealed adults.

The few weevils remaining active in the field developed sexually to some extent, some of the females attaining the state of developing ova and even full-sized eggs. Dissection of these adults revealed apparent disintegration of the sexual system, and apparently all died, since none was found to be intermixed with aestivating weevils. Moreover, the practice of abandoning alfalfa fields, with consequent absence of succulent food and cover during the heat of the summer and early fall months, militates against survival of these adults. Two seasons' study of these abnormal individuals shows conclusively that they are unimportant under Yuma Valley conditions.

\section{Abundance of Adults}

Late in April in 1939, extremely large numbers of adults congregated by day in grassy borders surrounding alfalfa varietal rows on the University of Arizona Valley Experiment Farm at Yuma. Considerable numbers also remained hidden about the base of alfalfa crowns. At night, alfalfa plants nearest to grassy areas were literally covered by adults, some plants having an estimated 200 to 400 on them, which resulted in rapid cefoliation. Samples from a sourclover breeding area in a pecan grove on April 30 contained an average of 72 adults per square foot. Adults crawled promiscuously on the ground and even in the trees. A nearby Bermuda grass lawn, with a sparse mixture of sourclover, contained 13 adults per square foot. Adults were fairly numerous on the University of Arizona Mesa Experiment Farm and the Oasis Ranch near the city limits of Yuma, but otherwise were scarce throughout the infested area. In alfalfa fields adjacent to the most heavily infested areas comparatively few adults existed. This was attributed, in part at least, to heavy migration following earlier harvest of the first hay crop.

In 1940 the production of adults was greatly curtailed because of a high mortality of the larvae. By way of comparison with 1939, continuous sampling of the most heavily infested sourclover breeding area on the Arizona Valley Experiment Farm showed a peak abundance of only 4 adults per square foot. Samples from the most favorable cover areas therein showed a peak of only 7 per square foot. In alfalfa varietal plots and nearby alfalia fields adults were actually difficult to cullect by sweeping methods. 
It was thus clearly demonstrated that the abunance of abilts ras much less than in 1939 and that the parent population for 1941 will be considerably less than in 1940, when it was considered very small. Factors inrolred in this decline of acult populations are believed to have been weather unsuitable for the development of the larvae and parasitization.

\section{Aestivation of Aciults}

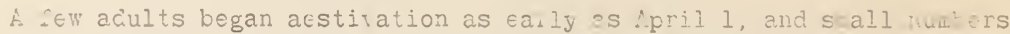
followed throughout the month. The greatest number entered aestiration early in May and virtually all were in this state by mid-llaj. Energ nce began late in Noremb r and appar ntly was complete ky January 1, the greatest exodus occurring curing the finst blif of December. The inter al batween earliest a stiation and carliest emorgenc as chout $T \frac{1}{2}$ rosihs, and this doubtless approximates the duration of the inactive period of most acults.

Aestilating a "ults congregated most conspicuolsly underneath the karls of growing trees and in trash piles affording the proper protective conditions. Large numbers also aestivated in cate palms where scalss and firs of old leaf stalks provide almost unlimitd facilitics. Smallor nomers passed the summer and fall in the soil and debris about tho haso of trocs, in heavily weeded areas, and in grassy citch an's. A f.h undoulticily survived in other situations. None was found wicir the karl of dead trues or fence posts or in the cracks and crevices of open farm builaings.

It rould appear that the aoults chose protectad locaiiors for atstivation in which there was a moderate amount of woistur with attwnat rojification of the temperature. A disturkance ô the proper ialance of either moisture or temperature caused adults to abancion aestivaiion places and scarch for others.

During the period of aestivation lasting thromgout the late spring, summer, and early -ail months acults did not ecu unaer outcioor or indoor conditions.

\section{Studies of Sexual Development}

Disscetions to follow the cuxual corclopment $c^{n}$ ral and ruale

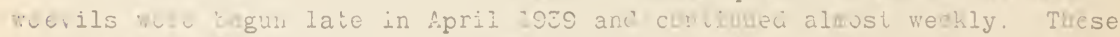
stucics t-ocul the sexual progrsss of a.ults curlng the puriod of aestilation and after their migration to lields wher all finally altained full maturity.

Diss cticrs of adults iuring fpril ard Mey soon after they witered

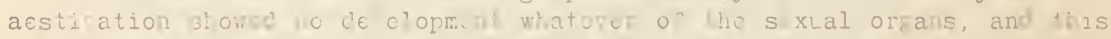

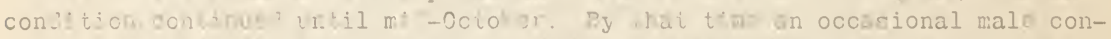

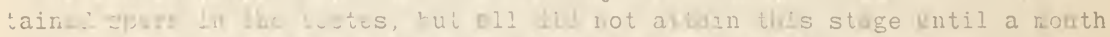

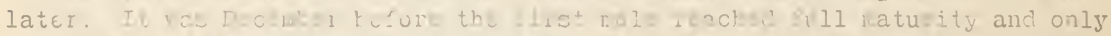

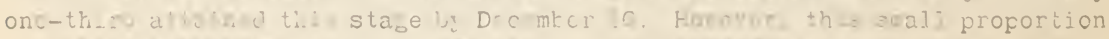

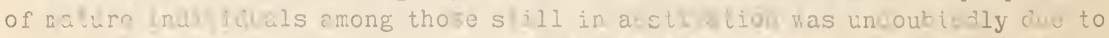

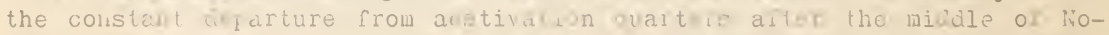
vember oi the acultis that were approbching suxual cuiusliy. The developuent 
of aestivating females lagged considerably behind that of males, showing but little ovarian development until mid-November. Segmentation vias observed on November 24 and developing ova on December 7 , but none attained the fullsized egg stage by December 16, the date of final dissections. It was thus indicated that females migrate to fields before attaining complete sexual maturity. None of the aestivating females was fertilized, indicating that mating does not occur until after migration to fields.

The initial collection from fields on November 24 of adults recently emerged from aestivation revealed some of the females with full-sized eggs and fertilized. All field-collected females were fully mature by December 30 and many were undoubtedly ovipositing. Almost one-third of the males in the field were fully mature on November 24 and all were fully mature by December 16. It is believed that the full maturity of all adults in the field indicated that emergence from aestivation was complete.

Night collections showed that a few adults of the current season remained active in the fields until late in June and developed sexually, a few males attaining full maturity. Occasional fertilization was attributed to the presence of old males, since new ones had not attained full maturity. although occasionally one exhibited sperm in the testes. These developing adults appeared to be abnormal and exhibited signs of internal discoloration and deterioration. Failure to encounter these during the summer and early fall, either in fields or in the course of regular dissections, clearly indicated that these developing adults die.

\section{Preoviposition Period}

The preoviposition period of Hypera brunneipennis is equal to the length of the aestivation period plus a 2- to 4-week post-aestivation feeding and mating period. Calculated in this manner, the preoviposition period is 8 to $8 \frac{1}{2}$ months.

\section{Oviposition}

Ecological samplings from an alfalfa field on December 12 failed to reveal eggs, but oviposition is believed to have hegun about December 17 the date of initial oviposition in laboratory cages. Oviposition was well under way by January 3 and was extremely heavy during January and the first half of February. The peak abundance of 65 eggs per square foot appeared on February 5. Thereafter the egg pcpulation declined and remained at a low level until none were found on or after April 2. It is therefore indicated that the oviposition period in the alfalfa study field this season was approximately $3 \frac{1}{2}$ months.

Similar studies in sourclover were not begun until late in the season, but it is unlikely that oviposition began on this host until about mid-January, since it failed to obtain an appreciable growth before that time. Initial studies on March 13 showed 74 eggs per square foot, but thereafter 
the number declined and remained at a low level. A few clusters of eggs were still present as late as May 6, the date of the final sarpling. It was thus indicated that oviposition in sourclover growths may continue a month or more longer than in alfalfa.

Individual oviposition records were not attempted, but average figures were obtained on three hosts by establishing bulk cages, each containing 10 pairs of adults. The cages were ordinary jelly glasses with a small amount of soil packed in their bottoms and with the original tin lids perforated to provide adequate fresh air. Fresh food and new dry stems were supplied on alternate days when counts were made. Adults confined on alfalfa were collected from aestivation early in December and records are complete. Cages containing huban or sourclover were not established until January 4 , when these plants first becaue available. Adults for these were swept from alfalfa, where they had already fed and oviposited for approximately 2 weeks. Consequently oviposition records for adults confined on these foods are not complete. The fact that these plants were not available to adults emerging from aestivation renders it certain that all adults fed initially on alfalfa and later dispersed to such other hosts as became available.

Oviposition in two alfalfa cages lasted for 4 and $4 \frac{1}{2}$ months, respectively, after initial eggs were deposited on December 19. Assuming that oviposition of the adults confined on hubam and sourclover began at the same time, the oviposition period for hubam cages was 3 and 5 months and for sourclover 3 and $3 \frac{1}{2}$ months. If calculated from the date of establishment, the oviposition period on both hubam and sourclover would be approximately 2 weeks shorter. Results indicate some slight differences in the duration of the oviposition period on various hosts, but the evidence is insufficient to warrant a final conclusion in this regard. On the basis of only one season's work it was indicated that huban and sourclover promoted equally heavy oviposition and alfalfa significantly less, in spite of the fact that records on the two first-named hosts were incomplete. Data are given in table 1

\section{Postoviposition Period}

Most caged females died before their complements of eggs were completely exhausted, and no spent females have yet been encountered in dissections of field-collected adults. In oviposition cages, however, a few females survived from 2 days to more than a month after final oviposition.

\section{Longevity of Adults}

f.dults began to die shortly after erergence from aestivation, but field and cage studies indicated that mortality was of small consequenco until early in Warch. Mortality of old adults was virtually complete by April 1, but a few individuals survived throughout May. In 1939 one was encountered as late as June 6. It was thus indicated that adults may 
Table 1.--Oviposition of Hypera brunneipennis under insectary conditions on alfalfa, hubam, and sourclover. Yuma, Ariz., December 1939 to May 1940

\begin{tabular}{|c|c|c|c|c|c|}
\hline & & Approximate & Number & of eggs der & osited \\
\hline age & $\begin{array}{l}\text { Date } \\
\text { established }\end{array}$ & $\begin{array}{l}\text { oviposition } \\
\text { period (months) }\end{array}$ & Total & $\begin{array}{l}\text { Mean eggs } \\
\text { per female }\end{array}$ & $\begin{array}{l}\text { Mean } \\
\text { average }\end{array}$ \\
\hline $\mathrm{fa}$ & Dec. 9 & 4 & 5,810 & $6051 /$ & \\
\hline & do. & $4 \frac{1}{2}$ & 5,158 & 580 l/ & 593 \\
\hline 2/ & Jan. 4 & 5 & 7,729 & 1,066 & \\
\hline & do. & 3 & 3,602 & 563 & 815 \\
\hline ver $\underline{2} /$ & do. & $3 \frac{1}{2}$ & 5,292 & 864 & \\
\hline & do. & 3 & 5,202 & 724 & 794 \\
\hline
\end{tabular}

I/ A mean number of 105.8 eggs per female was deposited on alfalfa before cages on other hosts were established. tablished.

2/ Adults used were already ovipositing when these cages were es-

aestivate for approximately 8 months, emerge, and survive for a further period of 5 or 6 months in the field, a total period of some 13 to 14 months The majority of adults apparently live from 10 to 11 months.

\section{Adult Dissemination}

Adults possess well-developed wings, but none have been observed in flight in the field or captured on tanglefoot screens. Attempts to force flight were unsuccessful. Adults are capable of flight, however, this having been observed on several occasions in the laboratory. Nothing is known concerning the frequency, the time, or the distance of adult flight in the field, and no evaluation of its importance in dissemination and spread can as yet be made. There was considerable local movement of adults by crawling, but it is unlikely that any great distances are thus covered, especially after the adults have established themselves satisfactorily in fields.

\section{THE EGG STAGE}

\section{Description}

The freshly deposited egg (fig. 1, C) is bright lemon yellow but becomes dusky or dark in appearance, usually in about a week. It is oval in shape, averaging $0.63 \mathrm{~mm}$. in length and $0.40 \mathrm{~mm}$. in width; the length ranges from 0.54 to $0.70 \mathrm{~mm}$. and the width from 0.36 to $0.44 \mathrm{~mm}$. 


\section{Where Eggs Are Laid}

Egg layirg in alfalfa fields was confined almost entirely to dead, dry alfalfa stems ccmposing the surface litter. Only a few clusters of eggs were encountered in living alfalfa stems or in living or dead grass stems. About 95 percent were deposited in small, dry, easily punctured stems $1.5 \mathrm{~mm}$. and less in diameter. Eggs were deposited in clusters ranging in size frcm 1 to 46 but comparatively few contained more than 25. The average cluster in dry stems of alfalfa fields contained 14.3 eggs.

Early egg laying in sourclover was also confined mostly to dead stems, but by early Narch the majority were contained in the growing stems, indicating a marked difference in adult reaction to the two hosts. The fact that virtually no eggs were found in stems of growing alfalfa suggests the possibility that this plant is an unsuitable host in this respect. This apparent reaction of the ovipositing adults to sourclover is closely analogous to the oviposition habits of Hypera postica on alfalfa in Utah and other States.

\section{Incubation Period}

The incubation period was determined under insectary conditions where temperatures closely approximated thcse in the field. Eggs were obtained from oviposition cages and ircubated in salve jars on moist blotting paper. Moisture was added in small amounts as neeced until hatching ceased. Except in a few instances, eggs for this study were obtained only from adults caged on alfalfa.

During most of January, when the prevailing mean cutdoor temperatures were about $54^{\circ} \mathrm{F}$., incubation required 20 to 22 days, but slightly warmer weather late in the month and early in February shortened the time to 16 to 19 days. By early March the incubation period had shortened to about 10 days and by early April, with outdoor mean temperatures of about $75^{\circ} \mathrm{F}$., it was only about 6 days. Incubation of several series of eggs late in the season frcm alfalfa, sourclover, and hubam indicated that the host plant of the parent adult had no significant bearing upon either the incubation period or the viability of eggs. Data on the incubation period are presented in table 2 .

\section{THE LARVAL STAGE}

Information concerning the larval stage (fig. 1, D) was obtained through measurements of larval head sizes, laboratory rearings, and periodic ecological samplings of alfalfa fields and sourclover patches, supplemented by general field observations.

\section{Description of the Larva}

Measurements of head sizes definitely showed that Hypera brunneipennis has four larval instars. Small numbers of measurements at intervals throughout the season showed no variation either in the number or the head size of 
Table 2.--Approximate duration of the incubation period of eggs of Hypera brunneipennis under insectary conditions, Yuma, Ariz., January to May 1940

Date deposited

Dec. 30 - Jan. 2

Jan. 6 - Jan. 8

Jan. 8 - Jan. 10

Jan. 12 - Jan. 14

Jan. 20 - Jan. 22

Jan. 26 - Jan. 29

Feb. 2 - Feb. 5

Feb. 5 - Feb. 7

Feb. 7 - Feb. 9

Feb. 10 - Feb. 12

Feb. 12 - Feb. 14

Feb. 16 - Feb. 17

Feb. 19 - Feb. 21

Feb. 24 - Feb. 26

Feb. 26 - Feb. 28

Mar. 2 - Mar. 4

Mar. 6 - Mar. 8

Mar. 8 - Mar. 11

Do.

Do.

Mar. 15 - Mar. 18

Do.

Do.

Apr. $10-$ Apr. 12
Incubation period (days)

Range Average

$21-24$

21.2

$\begin{array}{ll}21-23 & 21.5\end{array}$

$20-21 \quad 20.1$

22

22.0

$18-19 \quad 18.2$

$\begin{array}{ll}14-19 & 15.8\end{array}$

$19-22 \quad 19.4$

$17-21 \quad 18.2$

$17-21 \quad 18.3$

$16-17 \quad 16.2$

$15-21 \quad 15.9$

$13-16 \quad 14.1$

$11-15 \quad 11.9$

$\begin{array}{ll}10-14 & 11.8\end{array}$

$11-13 \quad 11.5$

$11-15 \quad 11.7$

$11-13 \quad 11.4$

$\begin{array}{ll}9-12 & 10.5\end{array}$

$9-12 \quad 10.0$

$9-12 \quad 10.3$

8 - 98.8

$\begin{array}{ll}8-9 & 8.8\end{array}$

$8-9 \quad 8.9$

$\begin{array}{ll}4-7 & 5.1\end{array}$

larval instars. Larvae of each stage vary greatly in body size and there is an overlapping between successive stages which renders classification on this basis uncertain. Results of head measurements of 100 specimens of each instar are shown in table 3.

Table 3.--Measurement of larval head sizes to determine number of instars, of Hypera brunneipennis, Yuma, Ariz., 1940

Number measured

$\begin{array}{ll}100 & \text { First } \\ 100 & \text { Second } \\ 100 & \text { Third } \\ 100 & \text { Fourth }\end{array}$

Larval

instar

Third

urth
First $\frac{\text { Width of head capsules (mm.) }}{\text { Range }}$

$\begin{array}{rr}0.195-.210 & 0.203 \\ .260-.300 & .285 \\ .395-.445 & .418 \\ .565-.650 & 607\end{array}$


The newly hatched first-stage larva is about one thirty-second of an inch in length. The body color varies from yellowish to light gray and the head is black. After feeding for a time the larva increases in size and the body usually assumes a somewhat dingy-gray color; the head remains black.

Immediately upon molting to the second stage the larval head is yellow, as it is after succeeding molts, but soon becomes dark. The body is aingy gray, but a few individuals acquire a faint greenish tinge immediately before molting to the third stage.

The head of the third-stage larva is mostly black but with traces of brown about the center. Its body is light green with a readily visible white stripe down the middle of the back.

The head capsule of the fourth-stage larva is almost entirely brown but with noticeable darkness about the edges, especially posteriorly. The body is light green with a broad white stripe down the middle of the back paralleled by smaller but distinct white stripes on each side. A limited number of measurements showed a range in bcdy length from one-fourth inch to almost one-half inch; the average body length was four-tenths of an inch.

Larvae of Hypera brunneipennis are similar to comparable stages of H. postica, and no distinguishing characteristics were discovered.

\section{Feeding Habits of Larvae}

Newly hatched larvae preferred the tenderest portions of host plants, usually being concentrated in the buds or stem tips and sheaths at the base of stems. Nany small larvae buried themselves in these tissues and remained hidden for short periods while feeding. Second-stage larvae fed in a similar manner but were usually more easily observed than the smaller first-stage larvae. Comparatively few of either stage could be collected by net-sweeping of plants.

Larger third and fourth instars also fed upon the tender portions of plants but most heavily upon the open leaves. Alfalfa leaves were skeletonized by intensive feeding, leaving only the principal leaf veins and sometimes portions of the lower epidermis. Larger larvae, however, feeding upon the thicker leaves of sourclover and hubam, tended to consume all the leaf tissues, making clean holes or ccmpletely removing portions of the leaves, thus giving a ragged appearance to the plant. In general, larvae concentrate first upon the uppermost portions of plants and move downward as the foliage is destroyed In the manner of feeding and damage inflicted Hypera brunneipennis appears to be identical with the alfalfa weevil (브. postica) on alfalfa.

Larvae that beccme dislodged from plaı.ts readily ascend and feed upon the nearest available host plant. They are capable of crawling short distances over dry exposed soil, if not too hot, and also over soil following irrigation. Larvae have been observed actually to remain in water for short periods and, after its subsidence, to ascend and resume feeding on the nearest host plant. 


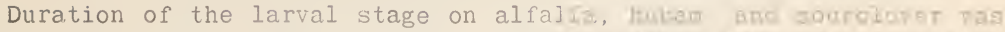
determined by bulk cage rearings begun on Jamanty 29 and 30 under 2racetary conditions where temperatures vere 2 to 4 cograne hather than thisu fn wac field. Each rearing consisted of a singlo cage for cabu bast suppl. $d$, th

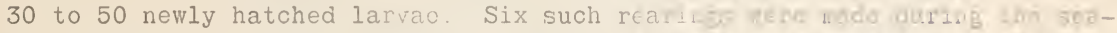

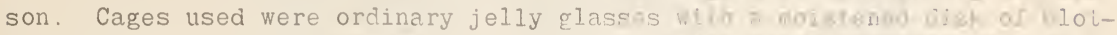
ting paper in the botto and a perforated tin 7 tri wholl provented fog rapid

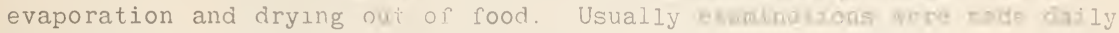
and fresh food was supplied.

Initial results indicated that larvak fsads esurixy au appooxudstoly 1 month, developing slightly faster on alfalfa thith on olfher fosts This period decreased considerably for each successipo mentug as itue gebaul edvanced, being only about 3 weeks by the gard of the saeson. In overy rearing larvae required slichtly less time to matrop on 3lfalka wan on sourclover or hubam, which appeared about equal

Data showing the comparative developmoni. Gy shegez, of larven on different hosts are given in table 4

\section{Larval Abundance and Development in the Filel}

The first newly hatched larvae appeared in alfalfa carly in is nuary but very few were present as late as January 15 although the abiniance of eggs gave promise of a sizeable population. In spite of carly expactations and continued oviposition, larvae never atiained an abuncance commenerate with that of eggs. Of the relatively small lartal population wich apporit, only a small fraction developed to the second stage and silil fentr to stoceeding stages. Apparently some factor or factors prevented nornal survial and development on alfalfa curing the 1940 seasol. Cccisionsl dead larva? were observed following a period of frosty nights curing the latte ial of January, and their death was attributed to that facior, sicce with the arvent of favorable weather larvae quickly doublcd in abrandarce. The population again declined following a second cold period keginning carly ir February and continued to do so during the renaincer of the month This ras due in part to a decline in oviposition, but the principal actor vas cortality. The fact that higi larval mortality in alfalfa persisted even after the advent of warm spring weather strongly incicated the usuitability of alfalfa as a larval host.

Information on the abundance and cievelopment of larvas cll sourclorer was not obtained during January, since this plant did $10^{2}$ chow appleciable growth until late in the month. Early in Felruary, how el, opseriations revealed larvae to be more iumerous in sourclover than in alfalsa flelus. and this was even more apparcnt late in the month Frosly ligh s oplanntly affected the population in the same manner as in alfalfa, but hine cecrease 
Table 4.--Duration of the larval stage of Hypera brunneipennis on alfalfa, hubam, and sourclover, Yuma, Ariz., 1940

\section{Length of larval stage (days)}

Date

Food

started

Mean days_in stages

lst 2nd $3 \mathrm{rd} \quad 4$ th

Range Mean

Alfalfa

$1 / 29$

6.6

8. 0

9.8

6.6

30-32

31.0

Hubam

$1 / 30$

7.0

10.1

8.1

7.2

30-40

32.4

Sourclover

9.3

8.2

7.6

7.6

29-36

32.7

Alfalfa

$2 / 12$

9.4

4.1

3.8

6.2

$23-27 \quad 23.5$

Hubam

$2 / 12$

10.0

5.6

5.8

7.0

27-32 28.4

Sourclover

$2 / 12$

9.7

5.1

6.9

23-24 26.9

Alfalfa

$2 / 24$

3. 6

4.3

4.3

7.8

20-22 20.0

Hubam I/

Sourclover

$2 / 25$

5.6

$--$

$--$

$---$

21-29 25.1

Alfalfa

$3 / 2$

Hubam

$3 / 2$

4. 0

3.8

6.4

5.9

19-21 20.1

Sourclover

$3 / 2$

5.9

5.5

5.7

5.0

7.4

2/

$21-27$

22.1

Alfalfa

$3 / 10$

6.8

4.4

4. 4

5.3

19-25 20.9

Hubam

$3 / 10$

7.0

4.2

4.6

6.1

Sourclover

$3 / 10$

7.8

4.9

4.2

2/

Alfalfa

$3 / 21$

3. 2

3.5

4.3

6.3

$\begin{array}{ll}17-21 & 17.3\end{array}$

Hubam

$3 / 21$

5.7

5. 2

5.4

5.1

19-23 21.4

Sourclover

$3 / 21$

4.9

4.2

4.2

6.4

$17-23 \quad 19.7$

I/ No cage established.

2/ Cage closed because of complete mortality.

was scmewhat ubscured by greater abundance of larvae resulting from a larger parent adult population. Ecological studies begun in sourclover on March 13 revealed a sizeable larval population and an abundance of eggs, indicating a continlied increase of larvae. However, the larval population failed to increase and socn began to decline, with relatively few developing to maturity. Ccmparison cf data on the two hosts indicated that sourclover was a more suitable host than alfalfa, but even on sourclover only a minor portion of the population developed to the adult stage. Consequently this plant must be considered only as the most satisfactory of the available hosts. Comparative data on the abundance and development of larvae on alfalfa and sourclover are presented in table 5. 
Table 5.--Comparative larval abundance and development by stages of Hypera brunneipennis in alfalfa and sourclover, Yuma, Ariz., 1940

\begin{tabular}{|c|c|c|c|c|c|c|}
\hline \multirow[b]{3}{*}{ Field } & \multirow{3}{*}{$\begin{array}{c}\text { Date } \\
\text { sampled }\end{array}$} & \multicolumn{5}{|c|}{ Number of larvae per square foot } \\
\hline & & \multicolumn{4}{|c|}{ Instar } & \multirow[b]{2}{*}{ Total } \\
\hline & & lst & 2nd & $3 \mathrm{rd}$ & 4 th & \\
\hline & Jan. 3 & - & - & -- & -- & - \\
\hline & Jan. 8 & - & - & - & - & -- \\
\hline & Jan. 15 & 0.75 & 0 & 0 & 0 & 0.75 \\
\hline & Jan. 22 & 16.00 & 2.00 & 0 & 0 & 18.00 \\
\hline "Date & Jan. 29 & 18.50 & 1.50 & 0 & 0 & 20.00 \\
\hline Grove" & Feb. 5 & 33.13 & 5.13 & 0 & 0 & 38.25 \\
\hline \multirow[t]{10}{*}{ alfalfa } & Feb. 14 & 25.63 & 6.25 & 0.75 & 0 & 32.63 \\
\hline & Feb. 20 & 19.13 & 4.25 & 0.25 & 0 & 23.63 \\
\hline & Mar. 5 & 3.88 & 4.00 & 0.25 & 0.13 & 8.25 \\
\hline & Mar. 19 & 9.25 & 0.88 & 0.50 & 0.38 & 11.00 \\
\hline & Mar 25 & 2.25 & 0.13 & 0.25 & 0.13 & 2.75 \\
\hline & Apr. 2 & 1.75 & 0 & 0.13 & 0 & 1.88 \\
\hline & Apr. 8 & 0.25 & - 0.25 & 0 & 0.13 & 0.63 \\
\hline & Mar. 13 & 9.86 & 5.43 & 4.43 & 5.43 & 25.14 \\
\hline & Mar. 20 & 16.00 & 3.86 & 2.71 & 3.57 & 26.13 \\
\hline & Mar. 27 & 9.14 & 6.86 & 4.86 & 3.29 & 24.14 \\
\hline "Pecan & Apr 2 & 7.00 & 3.29 & 4.57 & 7.00 & 21.86 \\
\hline Grove" & Apr. $10 \underline{1} /$ & 0.13 & 0.38 & 0.63 & 4.13 & 5.25 \\
\hline sour & Apr. 16 & 0 & 0 & 0 & 0.25 & 0.25 \\
\hline clover & Apr. 22 & 0 & 0 & 0 & 0 & 0 \\
\hline \multirow[t]{2}{*}{ area } & Apr. 29 & 0 & 0 & 0 & 0 & 0 \\
\hline & May 6 & 0 & 0 & 0 & 0 & 0 \\
\hline
\end{tabular}

1/Growth clipped on April 3, causing considerable mortality of immature larvae.

\section{THE PUPAL STAGE}

The pupal stage (fig. 1, E) is passed in thin, white, netlike cocoons, usually oval in shape. Mature larvae usually attach their cocoons to the growing leaves of host plants. One or more leaves may be utilized to provide satisfactory protection during this state of inactivity. A considerable number are also attached to dead leaves and stems above the ground. Comparatively few are spun in the surface litter or on the bare soil. The spinning of cocoons above the ground is not a seasonal habit but a characteristic of the species. In this respect Hypera brunneipennis differs from the alfalfa weevil (ㅂ. . postica), which spins most of its cocoons in the surface litter.

Shortly after spinning, the larva curls up and remains relatively inactive during a short period in which it gradually transforms into a pupa. 
The newly formed pupa is usually light green but as development progresses it gradually assumes the structure and light-bronze color of the adult. The exoskeleton of the newly formed adult is thin and soft, but in a few days it hardens and the adult is able to emerge from the cocoon.

\section{Duration of the Pupal Stage}

The duration of the prepupal and pupal periods was determined by continuing larval rearing cages until the emergence of adults.

During the early part of Warch the length of the prepupal period ranged from 4 to 11 days and averaged 4.0,4.3, and 4.9 days, respectively, for larvae reared on sourclover, hubam, and alfalfa. The duration of the pupal stage on these hosts ranged from 12 to 21 days and averaged 9.0, 11.1, and 10.2 dris, respectively. The length of the entire pupal period on sourclover, hukam, and alfalfa, respectively, was 13.0, 15.3, and 15.1 cays. Both the prepupal and pupal stages required fewer days during the remainder of March, and there vias no significant difference attributable to the larval food. The final rearing begun early in April revealed a marked shortening of the prepupal and pupal stages, with the entire pupal period requiring only 6.2 to 6.8 days. Adults remained in cocoons 2 to 5 days before emerging but most of them emerged in 2 to 3 days.

Data on the approximate duration of the pupal period are shown in table 6 .

Abundance and Development in the Field

Ecological studies in an infested alfalfa field throughout the 1940 season failed to reveal a cocoon containing either a larva or pupa, and only one empty cocoon was encountered. Many other fields were examined, but in only a few was an occasional cocoon observed. This clearly indicated that very few larvae survived and developed to maturity in alfalfa.

Similar studies in a heavily infested sourclover area showed that only a small proportion of a sizeable larval population survived to spin cocoons. Furthermore, only a minor portion of cocooned individuals reached the adult stage. This condition also prevailed in the many other sourclover areas observed. A portion of the mortality within cocoons probably was attributable to the same factor or factors that affected the larval population. There were, however, several known factors involved, principally cxposure to the sun, and parasites. The combined effect of the various factors influencing abundance and survival of pupae is shown by the data given in table 7 . 
Table 6.--Duration of the pupal period of larvae of Hypera brunneipennis reared on alfalfa, hubam, and sourclover, Yuma, Ariz., 1940

Length of pupal period (davs)

Larva $\perp$

food

Alfalfa

Hubam

Sourcluver

Alfal fa

Hubam

Sourclover

Al fal fa

Hubam ${ }^{1}$

Sourclover

Alfalfa

Hubam

Sourclover

Alfalfa

Hubam

Sourclover ${ }^{2}$

Alfal fa

Hubam

Sourclover

\section{$3 / 29$}

$3 / 31$

$3 / 15$

3/17

$3 / 21$

$3 / 23$

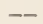

$4 / 7$

$4 / 9$

$4 / 7$
Prepupal stage

Range

Mean

4-11

4-15

4-11

4.9

4.2

4.0

$$
\text { 4-9 }
$$

5-9

4-15

2-8

3.7

4.0

5. 2

4.2

Pupal stage

Range Mean

Range

Mean

6-10

5.6

10.2

13-18

15. 1

11-17

11.1
9.0

15-21

15.3

13.0

$12-20$

13.9

11.7

11.8

$9-15$

9.9

13-15

$11-15$

13-19

9.3

8-12

4-12

2.1

2.1 6-11

6.2

$--$

8.3

\section{5}

6-12

6.6

8-14

9.1

2-6

3.1

6-13

7.7

$8-15$

10.8

\section{1/No cage established}

\section{$4.1 \quad 7-9$}

3.4

$4-9$
$2-4$

4-6

2-6

2-6
3.9

1.8

2.3
7-

2-7

4-9

4-9
6.4

6.3

11-13

9-

10.5

9.7

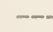

$\begin{array}{ll}2.3 & 6-11 \\ 5.0 & 6-11\end{array}$

$4.0 \quad 6-11$
6.2

6.8

6.3

Table 7.--Abundance and development of Hypera brunneipennis cocoons per square foot on sourclover, showing effect of mortality upon production of adults, Yuma, Ariz., March to May, 1940

\section{Date}

sampled

Miar 13

Mar 20

Mar 27

Apr 2

Apr. $10^{2}$

Apr. 16

Apr. 22

Apr. 29

May 6
Contents living

Total pupated

3.71

8.71

3.29

3.29

7.00

5.38

0.38

0

0

0
50.00

66.18

39.39

30.77

73. 21

88.37

100.00

2/Larvae died before cocooning
ent of Hvpera brunneipennis coco
, showing effect of mortality up
Yuma, Ariz., March to May, 1940

Number of

Contents Total

dead 1

(a11)

new adults

emerged

$\begin{array}{rr}0.14 & 3.85 \\ 1.00 & 9.71 \\ 1.43 & 4.72 \\ 0.57 & 3.86 \\ 6.63 & 13.63 \\ 11.00 & 16.38 \\ 4.25 & 4.63 \\ 2.25 & 2.25 \\ 0.29 & 0.29\end{array}$

0.29

0.71

1. 14

1.57

2.00

2.75

4.00

3.88

1.00

1/Total dead from all mortality factors.

2/Clipping growth on April 3 hastened cocooning of many maturing larvae. 


\section{SUMMARY OF SEASONAL HISTORY}

Except for a few individuals that remained active late in May and in June, Hycera brunneicennis acults were in aestivation from the middle of May until late in November, 1939, under the loose bark of growing trees, among the dead leaf stuks about the bases of date palms, and to a lesser extent in the soil and debris about the bases of trees, in heavily weeded areas, and in grassy ditch banks. Emergence of adults from aestivation was gradual and was completed by January 1, 1940, the greatest exodus having occurred during the first half of December.

Oviposition began in alfalfa fields about the middle of December, was at its height during January and early in February, and gradually declined to insignificance in early April. Eggs were abundant in sourclover as late as the middle of March and declined thereafter, although a few were still present as late as May 6. In alfalfa fields eggs were deposited almost entirely in pieces of dead, dry, easily punctured alfalfa stems in the surface litter in clusters of 1 to 46 . In sourclover patches early oviposition was also mostly confined to litter stems, but by the middle of March most of the eggs were contained in the living stems, indicating a marked difference in the adult reaction toward sourclover and alfalfa. During the cool weather of January eggs hatched in about 21 days, but as the weather became warmer the time gradually shortened to only 5 or 6 days in early April.

The larvae matured in 26 to 32 days during the winter months and in 17 to 22 days auring March and early April. The mortality of larvae feeding on sourclover in the field was very high and almost complete on alfalfa, relatively few finally attaining maturity. By the middle of April very few larvae remained either on sourclover or alfalfa.

A few larvae matured and formed cocoons as early as the end of February, but the majority matured and formed cocoons during the latter half of March and early April. The pupal period lasted about 15 days during early March but gradually shortened to 6 or 7 days during April.

The first new adults were otserved on March 13, and emergence was apparently complete by the end of April, the greatest number having emerged from late March to mid-April. By the micile of May practically all the newgeneration adults had completed feeding and gone into aestivation. Only one generation occurred during the year.

\section{HOST PLANTS}

Acults and larvae of Hypera brunneipennis have bcen observed to feed on alfalfa (Medicago sativa), hubam (annual form of Melilotus al $\underline{\text { ba }}$ ), bur-

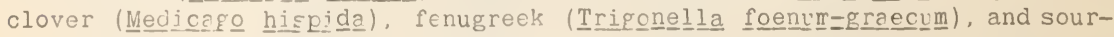
clover (Melilotus indica). Of thesc plants only alfalfa is of economic importance in the Yuma area, it being the principal forage crop. Hubam and sourclover are occasionally planted as green-manure crops but are mostly volunteer in citrus and pecan groves and along ditches and roadsides. Burclover exists only in small amounts, mostly in lawns. To date the growth of fenugreek has been limited to a few experimental patches. 
Other legumes, such as sesbania (Sesbanis macrocarpa) and guar (Cyamopsis tetragonoloba). are widely grown as green-manure crops during the summer months when the weevil is aestivating, and their status as hosts is not known.

Triplicate plantings of the following 10 legumes were made with a view to learning something about host range and preference; alfalfa (Medicago sativa), bur-clover (Medicago hispida), hubam (annual form of Melijlotus alba). sonrc cor (Melilotus indica). berseem clover (Trifolium alexandrinum), white Dutch clover (Trifolium alba), fenugreek (Trigonella foenum-graecum).

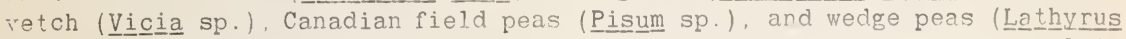
sp.). Hypera brunneipennis adult.s congregated naturally in these plots early in the season, making artificial infestation unnecessary.

Larvae fed to some extent upcr. all these species of plants except wedge peas and Canadian field peas. The total absence of feeding on those p? ants indicated that peas and possjhly beans may not be suitabje hosts On the other hand. it appeared that the species can mature successfully on alfalfa. the clovers, vetch, and fenugreek. More complete tests with other legumes would doubtless reveal many that would serve as hosts, at least to a limited extent

Larvae failed to survive and develop in numbers on any of these 10 legumes, thus obscuring any real differences in attractiveness. Early in the season larvae were most easjly found on alfalfa, but later this host harbored no more larvae than the clovers, and feeding on all was entirely negligible. Late in the season a large number of larvae were introduced in an effort to obtain definite indications as to the preferred host, but most of them apparently died within a short time.

Under natural field conditions weevil populations were considerably larger on sourclover than on alfalfa, but only a minor portion of the larvae survived to beccme adults. Therefure scurclover should not be considered a perfect host but rather the most suitable of those available. Further study must be given this phase before final conclusions can be made

\section{PARASITES}

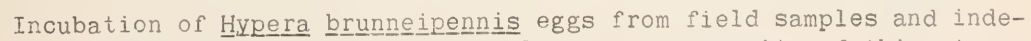
pendent field collections failed to reveal a single parasite of this stage. Parasites were reared from both the larval and pupal stages. These included at least one dipterous and three hymenopterous species, and positive identification of the quantity of material collected may reveal several others. Some of them may prove to be secondary parasites

Late in March and early in April parasites appeared to be of considerable importance, as almost one-third of the cocooned individuals from sourclover samples were affected Thereafter, however, the combined effectiveress of parasites declined to a relatively unimportant level. Larval parasitization was at all times negligible and confined to maturing individuals. These findings indicate that parasites may become a potent factor in curtailing the production of adults, but further studies must be made before their importance can be established conclusively. 


\section{ECONOMIC IMPORTANCE}

Populations of Hypera brunneipennis on alfalfa during the 1940 season were insufficient to inflict material injury to a single field. In no instance did feeding become noticeable or even approach damaging proportions. Larvae were fairly abundant and caused slight injury only in a few small patches of sourclover, a plant of no economic importance in the Yuma Valley of Arizona. This indicated that the insect is capable of inflicting damage under certain conditions, but too little is yet known of its potentialities to warrant a conclusion as to its status as an economic insect. All that can be said at this time is that winter and spring pasturing and cutting of alfalfa as regularly practiced in the Yuma Valley apparently would tend to prevent this insect from becoming a serious pest of this crop in that locality. 

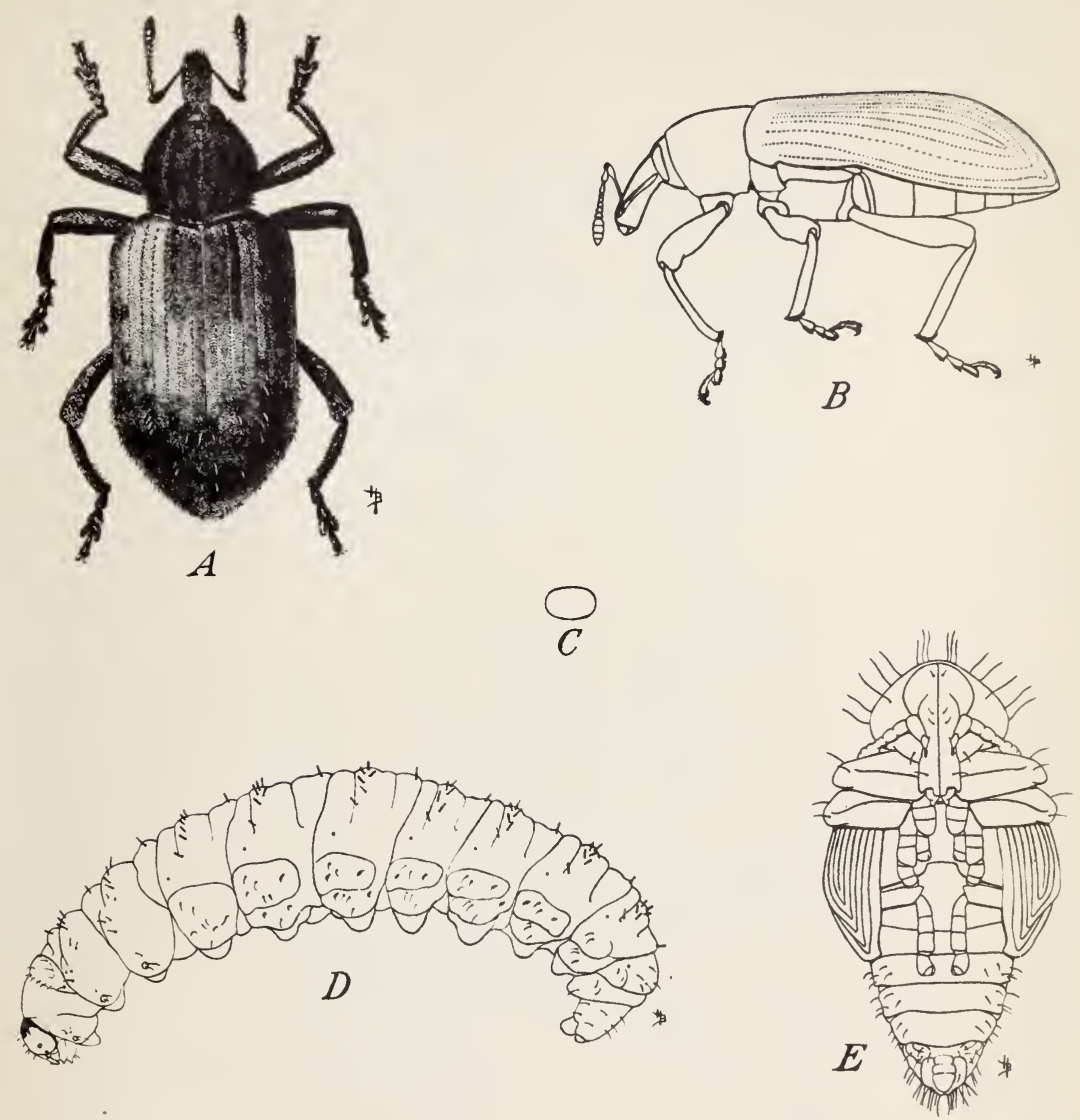

Figure 1.- Evpera brunneipennis: A, Adult beetle, dorsal Flew; B, adult, lateral view; C, egg; D, larva, Null-grown, lateral vlew;

E, pupa, ventral view. All greatly enlarged. 
